\title{
Preparation of test cells for the antiglobulin test
}

\author{
FRED STRATTON AND VIOLET I. RAWLINSON \\ From the Regional Blood Transfusion Service, Roby Street, Manchester
}

SYNOPSIS Erythrocytes may be coated with blood group antibodies with or without reacting complement or sometimes apparently with complement alone. This may occur in vivo in such conditions as autoimmune acquired haemolytic anaemia, haemolytic disease of the newborn, or after transfusions of incompatible blood. It may occur in vitro also by the deliberate sensitization of erythrocytes during laboratory serological investigations.

Blood group antibodies may be of immunoglobulin types $\gamma \mathrm{M}, \gamma \mathrm{A}$, or $\gamma \mathrm{G}$; we have never seen $\gamma \mathrm{D}$ antibodies. The presence of these antibodies on the erythrocyte surface, together with complement components or the presence of complement components alone, may be detected by the direct antiglobulin test where sensitization occurs in vivo or by the indirect antiglobulin test where there is sensitization in vitro.

The object of this paper is to describe the preparation of various kinds of sensitized red cells and their reactions with available specific antisera.

\section{Materials and Methods}

General methods are as previously described (Stratton and Renton, 1958).

\section{RED CELLS}

These are collected in acid citrate dextrose solution or in disodium EDTA solution (final concentration $0.01 \mathrm{M}$ ) and subsequently washed four times in normal saline before use.

LOW IONIC STRENGTH BUFFER FOR ONE LITRE (SVB) (RAPP AND BORSOS, 1963)

$97 \cdot 22 \mathrm{~g}$ sucrose

$1.019 \mathrm{~g}$ sodium barbitone

$0.0167 \mathrm{~g}$ calcium chloride

$0.017 \mathrm{~g}$ magnesium chloride

Adjust to $\mathrm{pH} 7 \cdot 4$ with $\mathrm{NHCl}$.

CRUDE CI PREPARATION (STRATTON AND RAWLINSON, 1965a)

Freshly collected serum which contains no atypical antibodies is centrifuged for 18 hours at $100000 \mathrm{~g}$ at $4^{\circ} \mathrm{C}$. The supernatant solution is carefully removed and the remaining pellet dissolved in $1 / 10$ the original volume of veronal buffer, $\mathrm{pH} 7 \cdot 4$, containing $\mathrm{Ca}^{++}$and $\mathrm{Mg}^{++}$.

Received for publication 3 January 1974.
ANTISERA

Anti-IgG, anti-IgM, and anti-IgA, together with anti-C, were prepared as previously described (Stratton, Gunson, and Rawlinson, 1962; Stratton, Rawlinson, Chapman, Pengelly, and Jennings, 1972). Anti- $\beta_{1 \mathrm{a}}$ was made from anti- $\beta_{1 \mathrm{c}}$, the latter prepared as previously described (Stratton, 1966). Such antisera, prepared by the injection into animals of zymosan-coated particles, often appear to be mixtures of anti- $\beta_{1 \mathrm{a}}$ and anti- $\alpha 2 \mathrm{D}$, and the anti- $\alpha 2 \mathrm{D}$ component may be of low titre and can be removed by the addition of purified $\alpha 2 \mathrm{D}$ protein (vide infra). Such anti- $\beta_{1 \mathrm{a}}$ antisera then give a single line in the $\beta_{1 a}$ position with aged serum. Anti- $\beta_{1 a}$ antiserum was also prepared as previously described (Stratton, 1966). Care must be taken to ensure that such antisera do not contain an anti- $\alpha 2 \mathrm{D}$ component.

Anti- $\alpha 2 D$ antiserum was prepared in two ways. First, by the neutralization of unwanted components from a general anti-C reagent that contained anti- $\beta_{1 \mathrm{a}}$, anti- $\beta_{1 \mathrm{e}}$, and anti- $\alpha 2 \mathrm{D}$. Neutralization was effected by the use of an $\mathrm{R} 4$ reagent heated at $60^{\circ} \mathrm{C}$ for one hour; this treatment is known to destroy $\alpha 2 \mathrm{D}$ component (West, Davis, Forristal, Herbst, and Spitzer, 1966). An anti- $\alpha 2 D$ serum was kindly provided by Dr K. Pondman of Amsterdam and this gave a line of identity with our antiserum. Secondly, antisera were produced by the injection into rabbits of a partially purified preparation of $\alpha 2 D$ prepared by ultrafiltration of aged serum on Sephadex G-200 followed by chromatography on 
DEAE cellulose and PVC block electrophoresis. Such an antiserum contained, in addition to anti$\alpha 2 \mathrm{D}$, anti-albumin and other minor components. These unwanted components were neutralized by the addition of albumin solution, previously heated at $60^{\circ} \mathrm{C}$ for 10 hours. The $\alpha 2 \mathrm{D}$ preparations were also used for the neutralization of antisera referred to above. The anti-C5 used in this paper was kindly given by Dr. H. J. Muller-Eberhard of La Jolla, USA; we are also grateful for gifts of anti- $\beta_{1 e}$ and anti- $\beta_{1 c}$.

\section{Notation}

$\mathrm{E}=$ erythrocyte, $\mathrm{A}=$ antibody, $\mathrm{EA}=$ human erythrocyte sensitized with human antibody.

The nature of the antibody is designated by a shortened version of the antibody concerned, so that $R h=$ anti- $R h$ antibody, $L^{a}=$ antiLewis antibody, $\mathrm{K}=$ anti-Kell antibody, etc, so ELe $^{\mathbf{a}}=$ human cells sensitized with anti-Lewis antibody. $\mathrm{C}=$ complement, $\mathrm{EC}=$ erythrocye sensitized with complement, $\mathrm{ELe}^{\mathrm{a}} \mathrm{C}=$ erythrocyte sensitized with Lewis antibody and complement, AIHA = autoimmune haemolytic anaemia; C3 = third component of complement, $\mathrm{C} 4=$ fourth component of complement, $\mathrm{C} 5=$ fifth component of complement, etc.
Results

CELLS SENSITIZED WITH ANTIBODIES OF DIFFERENT IMMUNOGLOBULIN SPECIFICITY (TABLE I)

\section{Cells coated with $\gamma M$ antibody}

Anti-Lewis antibody was shown by Stratton (1961) to be a $\gamma \mathrm{M}$ antibody, and group $0 \mathrm{Le}(\mathrm{a}+)$ cells treated with this antibody may be used as a source of test cells for anti- $\gamma \mathrm{M}$ activity.

Ele $^{a}$ for use as $\gamma \mathrm{M}$-coated cells are prepared by mixing $4 \mathrm{vol}$ of a potent anti-Le $\mathrm{L}^{\mathrm{a}}$ serum containing a final concentration of $0.01 \mathrm{M} \mathrm{Na}$ EDTA with $1 \mathrm{vol}$ of $10 \%$ washed group $0 \mathrm{Le}(\mathrm{a}+)$ cells. Thirty minutes' incubation at $37^{\circ} \mathrm{C}$ is then followed by four washes in normal saline. These sensitized cells retain their activity for one to two days if kept at $4^{\circ} \mathrm{C}$. The use of a large proportion of antibody to cells may cause the sensitized cells to be agglutinated in saline even after washing. Therefore, with a given anti-Le ${ }^{a}$ serum, a compromise must be reached to give the strongest possible reaction with anti- $\gamma \mathrm{M}$ which is consistent with a negative saline control for a particular technique in the antiglobulin test.

It is necessary, however, to have a very potent antibody. Table II shows the titration of an antiLewis antibody with decreasing volumes of antiserum

\begin{tabular}{|c|c|c|c|c|c|}
\hline \multirow[t]{2}{*}{ Antiglobulin Sera } & \multicolumn{5}{|l|}{ Test Cells } \\
\hline & $E L e^{a}$ & $E \gamma A$ & $E R h(i)$ & $E R h(i i)$ & $E K$ \\
\hline $\begin{array}{l}\text { Anti- } \gamma \mathbf{M} \\
\text { Anti- } \gamma \mathbf{A} \\
\text { Anti- } \gamma \mathbf{G} \\
\text { Anti-C }\end{array}$ & $\begin{array}{l}+++++ \\
- \\
-\end{array}$ & $\begin{array}{l}- \\
+ \\
-\end{array}$ & $\begin{array}{l}- \\
\dot{+}+++\end{array}$ & $\begin{array}{l}- \\
\overline{+} \\
-\end{array}$ & $\begin{array}{l}- \\
- \\
+ \\
-\end{array}$ \\
\hline
\end{tabular}

Table I Reactions of test cells sensitized with antibodies of different immunoglobulin specificities in the antiglobulin test

\begin{tabular}{|c|c|c|c|c|}
\hline \multirow[t]{3}{*}{ ELe $e^{a}$-Volumes (Anti Le $e^{a}$ to Unit Vol $10 \% E$ ) } & \multicolumn{4}{|c|}{ Antiglobulin Tests } \\
\hline & \multicolumn{2}{|l|}{$E L e^{a}$} & \multicolumn{2}{|l|}{$E L e^{a}+C$} \\
\hline & Anti- $\gamma M$ & Saline & Anti-C & Saline \\
\hline $\begin{array}{l}10 \\
4 \\
2 \\
1 \\
0 \cdot 5 \\
0 \cdot 25 \\
0 \cdot 1\end{array}$ & $\begin{array}{l}+++++ \\
++++ \\
+++ \\
+ \\
- \\
=\end{array}$ & $\begin{array}{l}++ \\
- \\
- \\
- \\
-\end{array}$ & $\begin{array}{l}+++++^{1} \\
+++++^{1} \\
+++++1 \\
+++++ \\
+++++ \\
+++++ \\
+++++\end{array}$ & $\begin{array}{l}++ \\
- \\
- \\
- \\
- \\
-\end{array}$ \\
\hline
\end{tabular}

Table II Antiglobulin tests on Elea prepared in decreasing strength with and without addition of $C$ 


\begin{tabular}{|c|c|c|c|c|c|c|}
\hline \multirow[t]{3}{*}{ Treatment of ELea } & \multirow{3}{*}{$\begin{array}{l}\text { Lysis of Treated ELe } \\
\text { by Fresh Absorbed } \\
\text { Rabbit Serum }\end{array}$} & \multicolumn{5}{|c|}{ Antiglobulin Tests } \\
\hline & & \multicolumn{3}{|l|}{$E L e^{a}$} & \multicolumn{2}{|c|}{ On Treated ELe $e^{a}+C$} \\
\hline & & Anti- $\gamma M$ & Anti-C & Saline & Anti-C & Saline \\
\hline $\begin{array}{l}\text { 0.2M Mercaptoethanol } \\
\text { Buffered saline } \\
\text { Lea substance }\end{array}$ & $\begin{array}{r}0 \\
100 \\
0\end{array}$ & $\bar{t}+t+$ & $\begin{array}{l}- \\
-\end{array}$ & $\begin{array}{l}- \\
-\end{array}$ & $\vec{t}++t+$ & $\begin{array}{l}- \\
-\end{array}$ \\
\hline
\end{tabular}

Table III Effect of treatment of ELe $e^{a}$ with $0.2 M$ mercaptoethanol or Le $e^{a}$ substance on the antiglobulin test

mixed with a standard volume of red cells and the results of testing the sensitized cells in the antiglobulin test. It will be seen that only when a large volume of antiserum is mixed with a small volume of cells are the cells sufficiently strongly sensitized in the absence of complement to give a positive result with anti- $\gamma \mathrm{M}$. It can be shown, furthermore

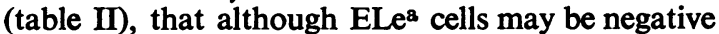
with anti- $\gamma \mathrm{M}$, the cells will still fix complement very strongly, suggesting that antibody is still absorbed on to the surface but probably in insufficient quantity to support agglutination by anti$\gamma \mathrm{M}$.

Experiments similar to those described by Stratton et al (1962) and Stratton, Smith, and Rawlinson (1968) have shown that either shaking sensitized cells Ele ${ }^{2}$ with $0 \cdot 2 \mathrm{M}$ mercaptoethanol, or treating them with $\mathrm{ELe}^{\mathrm{a}}$ substance, prevents their agglutination by anti- $\gamma \mathrm{M}$ antibody and it removes their ability to fix $\mathbf{C}$ (table III). The reactions of ELe $^{\mathrm{a}}$ may also be compard with the reactions of ELe $^{a} \mathrm{C}$ since ELe ${ }^{\mathrm{a}}$ fixes complement.

\section{Cells coated with $\gamma G$ antibody red cells}

Group 0 erythrocytes are coated with either anti-Rho (D) or anti-Kell antibodies.

Two volumes of antibody-containing serum at the required dilution (vide infra) are mixed with 1 vol of $10 \% \mathrm{Rh}$ (D)-positive cells (or Kell-positive cells) and incubated for 20 minutes at $37^{\circ} \mathrm{C}$, then washed four times. To prepare EK using a complement-fixing anti-K antibody, a final concentration of $0.01 \mathrm{M} \mathrm{Na}$ EDTA is added to the antiserum before mixing with the cells.

\begin{tabular}{|c|c|c|}
\hline \multirow{2}{*}{$\begin{array}{l}\text { EK } \\
\text { (Volumes of Anti-K } \\
\text { to Unit Vol } 10 \% E)\end{array}$} & \multicolumn{2}{|c|}{ Antiglobulin Test } \\
\hline & $\begin{array}{l}E K \\
A n t i-\gamma G\end{array}$ & $\begin{array}{l}E K+C \\
\text { Anti-C }\end{array}$ \\
\hline $\begin{array}{l}1 \cdot 0 \\
0 \cdot 1 \\
0.05 \\
0.01\end{array}$ & $\begin{array}{l}++++ \\
+++ \\
+++ \\
++\end{array}$ & $\begin{array}{l}+++++ \\
+++ \\
=\end{array}$ \\
\hline
\end{tabular}

Table IV Antiglobulin tests on EK prepared in decreasing strength with and without addition of $C$
Anti-D and anti-K exist as $\gamma \mathrm{G}$ antibodies; anti-D antibodies are not complement fixing but anti-Kell often are. It is possible, therefore, to obtain cells in the form EK and EKC for comparison. Table IV compares the strength of results with anti- $\gamma \mathrm{G}$, given for example EK made with different proportions of antiserum to cells and the results obtained with anti-C after they have been treated with C. This shows, in contrast to ELe 8 (table II), that it is possible to prepare sensitized cells EK using a $C^{\prime}$-fixing anti-Kell where the antibody can be detected but which do not fix detectable amounts of complement.

It is easy to prepare red cells sensitized with $\gamma \mathrm{G}$ anti-D which give an extremely high titre with anti- $\gamma \mathrm{G}$ reagent in the antiglobulin test, but it is useful to have more feebly sensitized cells in the test panel, since these tend to give a prozone effect and it is important to be sure that the anti- $y$ G reagent does not miss weakly sensitized cells at the dilution one is using. In view of the difficulties sometimes encountered in detecting cells sensitized with certain examples of $\gamma \mathrm{G}$ anti-Fy ${ }^{2}$ or anti-Jk ${ }^{\mathbf{a}}$ antibodies, they may (with advantage) be included as test cells.

\section{Cells coated with $\gamma A$ antibody}

Gamma A blood group antibodies are very uncommon. Rockey and Kunkel (1962) described an anti-A $\gamma \mathrm{A}$ antibody, and in our experience $\gamma \mathrm{A}$ anti-A antibodies are more likely to occur in hyperimmunized individuals. Group A cells, treated with $\gamma \mathrm{A}$ antibodies, have been used by us as a source of test cells but are not very satisfactory owing to the fact that they tend to agglutinate spontaneously in saline.

Engelfriet, von dem Borne, von dem Giessen, Beckers, and van Loghem (1968) and Stratton et al (1972) have described cases of acquired haemolytic anaemia in which the patients' cells were coated with $\gamma \mathrm{A}$ antibody and $\gamma \mathrm{A}$ anti-e antibody was found in the serum, and although in the latter case the titre of an anti-e antibody was low it did permit the preparation of $\gamma \mathrm{A}$-sensitized cells. Worlledge and Blajchman (1972) have reported three cases 
where the direct antiglobulin test was positive with anti- $\gamma \mathrm{A}$ alone in 121 cases of warm AIHA, indicating the frequency of such sensitized cells. The present authors have investigated two cases of AIHA in which the patients had $\gamma \mathrm{A}$-coated cells but no free antibody in the serum. Such sensitized cells made good test cells for $\gamma \mathrm{A}$ activity and are usually referred to as $\mathrm{E} \gamma \mathrm{A}$ because of the unknown specificity of the antibody on the erythrocyte. Such test cells may be stored in the frozen state. It is not possible under these circumstances to vary the strength of cell sensitization.

\section{CELLS COATED WITH COMPLEMENT AND ITS VARIOUS COMPONENTS (TABLE V)}

\section{Preparation of cells coated with complement}

These are usually made using the low ionic strength method. Mollison and Polley (1964) and Stratton and Rawlinson (1965b) independently described the uptake of complement by cells at low ionic strength and the latter authors suggested that these cells would be valuable as test cells. Such cells, referred to as EC, are simply and rapidly prepared.

\section{Preparation of EC}

Ten $\mathrm{ml}$ sucrose-veronal buffer containing $0.25 \mathrm{ml}$ of normal mixed fresh serum and $0.2 \mathrm{ml}$ washed packed group 0 cells are incubated at $37^{\circ} \mathrm{C}$ for 10 minutes followed by four washes in normal physiological saline (table V). It will be seen that these cells are negative with anti- $\gamma \mathrm{M}, \gamma \mathrm{A}$, and $\gamma \mathrm{G}, \bar{c}$ strongly agglutinated by anti- $\beta_{1 \mathrm{e}}$ and $\beta_{1 \mathrm{a}}$, and less strongly agglutinated by anti- $\alpha 2 D$. If kept in a saline suspension for more than four hours the $\beta_{1 \mathrm{a}}$ begins to leach off, though the reactivity with anti- $\beta_{1 \mathrm{e}}$ and anti- $\alpha 2 \mathrm{D}$ remains undiminished for much longer periods. Table VI shows the reactions $\vec{\circ}$ of EC prepared under different conditions of time, $\overrightarrow{\vec{\omega}}$ dilution of $\mathrm{C}$ and ionic strength of buffer, and it will $\stackrel{\omega}{\omega}$ be seen that using $C$ in higher dilutions than 1 in 40 웅 or an ionic strength only one fifth greater than is 0.009 , gives much weaker results in the antiglobulin $v$ tests and produces cells coated with $\mathrm{C} 4$. No par- $\dot{\omega}$ ticular advantage is gained by incubating the cells for $\overparen{\mathcal{O}}$ longer periods - 10 minutes is quite sufficient to 을 give very satisfactory results.

$E^{2} e^{a}$ and EK, as noted previously, will fix com- $\bar{z}$ plement and become ELe ${ }^{\mathrm{a} C}$ and EKC, and the reactions of these cells with the various reagents $\overrightarrow{0}$ are shown in table $V$. If undiluted $C$ is added to sensitized cells in the form EA, or if antibody and $\mathrm{C}$ are added together to $\mathrm{E}$, strong agglutination with anti- $\beta_{1 e}$, anti- $\beta_{1 a}$ and anti- $\alpha 2 \mathrm{D}$ results (cf EC). Such cells also react with anti-C5 but EC produced as described above by the low ionic strength method $\frac{\mathrm{O}}{\mathrm{O}}$

\begin{tabular}{|c|c|c|c|c|c|c|c|c|}
\hline \multirow[t]{2}{*}{ Antigobulin Sera } & \multicolumn{8}{|l|}{ Test Cells } \\
\hline & $E C$ & $E H C$ & $E C 4$ & $E C 4(A n t i-I)$ & $E C 3$ & $C A H A^{1}$ & $E L e^{a} C$ & $E K C$ \\
\hline Anti C & $+t+t+$ & $+t+t+$ & ++++ & $++t+$ & +++ & $+t+t+$ & $+t+t+$ & $+++t$ \\
\hline Anti $\beta_{1 e}$ & $++t+t$ & $+t+t+$ & ++++ & $++t$ & - & & $+t+t$ & $+t+t$ \\
\hline Anti $\beta_{18}$ & $++t+t$ & + & - & - & +++++ & - & $++t+$ & $++t+$ \\
\hline Anti $\alpha 2 D$ & $+t+$ & ++ & - & - & - & $++t+t$ & $++t+t$ & $+t+$ \\
\hline Anti C5 & - & - & - & - & - & + & $+t+$ & + \\
\hline Anti $\gamma M$ & - & - & - & - & - & - & $++t$ & - \\
\hline Anti $\gamma \mathbf{A}$ & - & - & - & - & - & - & - & - \\
\hline Anti $\gamma \mathrm{G}$ & - & - & - & - & - & - & - & $+t+t+$ \\
\hline
\end{tabular}

Table V Reactions of test cells coated with complement and various complement components in the antiglobulin test

'Patients' cells from case of cold acquired haemolytic anaemia

\begin{tabular}{|c|c|c|c|c|c|c|c|}
\hline \multirow[t]{2}{*}{ Jonic Strength of Buffer } & \multirow{2}{*}{$\begin{array}{l}\text { Dilution of C } \\
\text { in Buffer }\end{array}$} & \multirow{2}{*}{$\begin{array}{l}\text { Time of } \\
\text { Incubation }\end{array}$} & \multirow{2}{*}{$\begin{array}{l}\text { Temperature }\left({ }^{\circ} \mathrm{C}\right) \\
\text { of Incubation }\end{array}$} & \multicolumn{4}{|c|}{ Antiglobulin Test } \\
\hline & & & & Anti- $\beta_{1 e}$ & Anti- $\beta_{1} a$ & $A n t i-\alpha 2 D$ & Anti-C5 \\
\hline 0.009 & $\begin{array}{l}1 \text { in } 20 \\
1 \text { in } 40 \\
1 \text { in } 100 \\
1 \text { in } 200\end{array}$ & $10(\min )$ & 37 & $\begin{array}{l}+++++ \\
+++++ \\
++++ \\
+++\end{array}$ & $\begin{array}{l}+++++ \\
++++t \\
++ \\
-\end{array}$ & $\begin{array}{l}+++ \\
+++ \\
- \\
-\end{array}$ & $\begin{array}{l}++ \\
- \\
-\end{array}$ \\
\hline \multirow{6}{*}{$\begin{array}{l}0.023 \\
0.037 \\
0.065 \\
0.009\end{array}$} & 1 in 40 & 10 & 37 & +++ & - & - & \\
\hline & & & & & & - & \\
\hline & 1 in 40 & 30 & 37 & $+t+t$ & $++t+t$ & $++t$ & - \\
\hline & & $\begin{array}{l}10 \\
30\end{array}$ & $\begin{array}{l}20 \\
20\end{array}$ & $\begin{array}{l}+ \\
+t+t+\end{array}$ & $\bar{t}+$ & - & \\
\hline & & 10 & 4 & - & - & - & \\
\hline & & 30 & 4 & - & - & - & \\
\hline
\end{tabular}

Table VI EC prepared under various conditions 


\begin{tabular}{|c|c|c|c|c|c|}
\hline \multirow{2}{*}{$\begin{array}{l}1 \\
\text { Sensitized Cells }\end{array}$} & \multirow{2}{*}{$\begin{array}{l}2 \\
\text { From Column I Cells } \\
+10 \text { Vol C }\end{array}$} & \multicolumn{4}{|c|}{ Antiglobulin Test on Cells from Column 2} \\
\hline & & Anti- $\beta_{1 e}$ & Anti- $\beta_{1 a}$ & Anti-x2D & Anti-C5 \\
\hline ELe ${ }^{a}$ & $\begin{array}{l}\text { Undiluted } \\
1 \text { in } 20 \\
1 \text { in } 100 \\
1 \text { in } 1000\end{array}$ & $\begin{array}{l}+++++ \\
+++++ \\
+++++ \\
++++\end{array}$ & $\begin{array}{l}+++++ \\
++++\div \\
++ \\
-\end{array}$ & $\begin{array}{l}++++ \\
+++ \\
++ \\
-\end{array}$ & $\begin{array}{l}++++ \\
+++ \\
- \\
-\end{array}$ \\
\hline EK & $\begin{array}{l}\text { Undiluted } \\
1 \text { in } 20 \\
1 \text { in } 100\end{array}$ & $\begin{array}{l}++++ \\
+++++ \\
++++\end{array}$ & $\begin{array}{l}+++++ \\
+++ \\
-\end{array}$ & $\begin{array}{l}+++ \\
+++ \\
-\end{array}$ & $\begin{array}{l}+ \\
-\end{array}$ \\
\hline
\end{tabular}

Table VII Complement-coated cells using complement-fixing blood group antibodies

${ }^{1}$ Some haemolysis

usually do not. If very dilute $\mathrm{C}$ is added to sensitized cells $\mathrm{ELe}^{\mathrm{a}}$ or $\mathrm{EK}$, positive results are only obtained with anti- $\beta_{1 \mathrm{e}}$; the agglutination with anti- $\beta_{1 \mathrm{a}}$ decreases as the dilution of $\mathrm{C}$ is increased (table VII).

CELLS COATED WITH C4 COMPONENT OF COMPLEMENT IN THE ABSENCE OF ANTIBODY

Cold incomplete anti-H antibody, originally described by Dacie (1950), and its specificity, detailed by Crawford, Cutbush, and Mollison (1953), has often been used to make cells coated with $\mathrm{C} 4$ alone.

\section{Preparation of EHC}

Ten volumes of fresh serum (Group AB), known to contain strong anti-H, plus 1 volume of packed washed group 0 cells are incubated in melting ice for 35 minutes, then washed four times in normal saline at room temperature, and the results of testing such sensitized cells with the reagents are shown in table V. In the majority of cases, these cells are found to give positive results with anti- $\alpha 2 \mathrm{D}$ antiserum.

\section{Preparation of EC4 (low ionic strength method)}

To $10 \mathrm{ml}$ low ionic strength sucrose veronal buffer (SVB) is added $0.25 \mathrm{ml} \mathrm{Cl}$ preparation together with $0.2 \mathrm{ml}$ packed, washed cells. The mixture is incubated for 10 minutes at $37^{\circ} \mathrm{C}$ and then the cells are packed and washed twice in SVB. These cells are then added to a solution consisting of $10 \mathrm{ml} \mathrm{SVB}$ and $0.25 \mathrm{ml}$ inactivated normal human serum (15 minutes at $56^{\circ} \mathrm{C}$ ). This mixture is then agitated for one minute at room temperature and the cells are washed four times in normal saline. Table $V$ shows that cells prepared in this way are strongly agglutinated by anti- $\beta_{1 e}$ alone. Here, weakly sensitized cells can be produced by using more dilute $\mathrm{Cl}$ pellet and/or heated serum. The time of incubation is very short and no advantage is gained by increasing it. Cells in the form EC4 can also be prepared at normal ionic strength using anti-I eluate of appropriate dilution with $\mathrm{Cl}$ to make $\mathrm{EICl}$ at $4^{\circ} \mathrm{C}$ followed by the addition of heated human serum (table V).

\section{CELLS COATED WITH C 3}

C3 is $\beta_{1 \text { c }}$ globulin, described by Müller-Eberhard, Dalmasso, and Calcott (1966) and bears a number of antigenic determinants as described by West et al (1966). Bokisch, Müller-Eberhard, and Cochrane (1969) showed that $\mathrm{C} 3$ has a fragment, $C 3_{\mathrm{a}}$, which acts as an anaphylatoxin and $\mathrm{C}_{\mathrm{b}}$, which itself can be cleft by enzymic action into two antigenically distinct pieces, $C 3_{c}$ corresponding to $\beta_{1 \mathrm{a}}$ and $\mathrm{C} 3_{\mathrm{d}}$ corresponding to $\alpha 2 \mathrm{D}$.

Cells coated with C3 alone are difficult to prepare. Jenkins, Christenson, and Engles (1966), showed that postacid lysis PNH cells were agglutinated by anti$\beta_{1 \mathrm{c}}$ alone and previously we had used such test cells, carefully prepared with repeated passages through acidified serum, to give the strongest possible result. However, the cells were never very strongly agglutinated. Other methods of preparing cells coated with $\mathrm{C} 3$ have been tried. Methods have been employed of activating the alternate pathway in the presence of red cells (Götze and MüllerEberhard, 1971), for example, by the addition of inulin or cobra venom to serum. We have also tried the methods described by Abramson, Alper, Lachmann, Rosen, and Jandle (1971). Nicol and Lachmann (1973) have also described an alternative method of making such cells. We have come to the conclusion that treatment of a serum-cell mixture with inulin produces cells coated with $\mathrm{C}^{\prime} 3$ suitable for our purpose.

Ten $\mathrm{ml}$ of fresh normal serum (average $\mathrm{pH} \mathrm{7.8)}$ and $0.5 \mathrm{ml}$ of $10 \%$ washed group 0 cells are warmed to $37^{\circ} \mathrm{C}$ and mixed together. After five minutes, $0.3 \mathrm{ml}$ of a $5 \%$ suspension of inulin in saline is added and the mixture is incubated for a further five minutes at $37^{\circ} \mathrm{C}$. The cells are then washed in the usual way.

Table VIII shows these cells tested with various antisera. For convenience the cells are labelled EC3, but it seems possible from the results that they 


\begin{tabular}{|c|c|c|c|c|c|c|}
\hline \multirow[t]{2}{*}{ Test Cells } & \multirow{2}{*}{$\begin{array}{l}\text { Treated with Fresh Serum } \\
+E D T A\left(37^{\circ} C\right)\end{array}$} & \multicolumn{5}{|c|}{ Antiglobulin Tests } \\
\hline & & Anti-C & Anti- $\beta_{1 e}$ & Anti- $\beta_{1} a$ & Anti- $\alpha 2 D$ & Anti-C5 \\
\hline EC3 & $\begin{array}{l}0 \mathrm{~min} \\
10 \mathrm{~min} \\
30 \mathrm{~min} \\
120 \mathrm{~min}\end{array}$ & $\begin{array}{l}+t+ \\
+t+ \\
++t \\
++t\end{array}$ & $\begin{array}{l}- \\
- \\
-\end{array}$ & $\begin{array}{l}++t+t \\
+t \\
+ \\
-\end{array}$ & $\begin{array}{l}- \\
++ \\
++t \\
+++\end{array}$ & $\begin{array}{l}- \\
- \\
-\end{array}$ \\
\hline
\end{tabular}

Table VIII Reactions of EC3 cells before and after treatment with fresh serum + EDTA

\begin{tabular}{|c|c|c|c|c|}
\hline \multirow[t]{2}{*}{ Anticoagulant } & \multirow{2}{*}{$\begin{array}{l}\text { Time After Collection Before } \\
\text { Cells Washed at } 37^{\circ} \mathrm{C}\end{array}$} & \multicolumn{3}{|c|}{ Antoglobulin Tests } \\
\hline & & $A n t i-\beta_{1} \mathrm{e}$ & $A n t i-\beta_{1 a}$ & $A n t i-\alpha 2 D$ \\
\hline $\begin{array}{l}\text { EDTA (warm) } \\
\text { ACD (cold) } \\
\text { Nil (clotted) } \\
\text { ACD } \\
\text { Clotted } \\
\text { ACD }\end{array}$ & $\begin{array}{l}24 \mathrm{hrs}^{1} \\
72 \mathrm{hrs}\end{array}$ & $\begin{array}{l}- \\
+++ \\
++++ \\
+ \\
- \\
-\end{array}$ & $\begin{array}{l}- \\
++++ \\
++++t \\
++ \\
++ \\
-\end{array}$ & $\begin{array}{l}+++++ \\
+++++ \\
+++++ \\
+++++ \\
+++++ \\
+++++\end{array}$ \\
\hline
\end{tabular}

Table IX Effect of method of collection on cold AHA cells to be used as $\alpha 2 D$ coated test cells

${ }^{1}$ Stored at $4^{\circ} \mathrm{C}$

may be coated with $\mathrm{C} 3 \mathrm{~b}$; after incubation with sera which show no complement activity but contain $\mathrm{C} 3 \mathrm{~b}$ inactivator, the cells become changed as previously described (Abramson et al 1971), give positive results with anti- $\alpha 2 \mathrm{D}$, and are completely negative with anti- $\beta_{1 \mathrm{a}}$ after two hours' incubation at $37^{\circ} \mathrm{C}$. As previously mentioned, $\beta_{1 \mathrm{a}}$ does leach from a saline suspension of EC cells and this occurs even more rapidly from EC3 so that after two hours in saline at $37^{\circ} \mathrm{C} \mathrm{EC3}$ will no longer be agglutinated by anti- $\beta_{1 a}$ nor anti- $\alpha 2 D$. Thus, although on EC3 $\beta_{1 \mathrm{a}}$ may be weakly bound, when treated with fresh serum (table VIII), the $\alpha 2 \mathrm{D}$ appears more strongly bound..

Engelfriet, Pondman, Wolters, von dem Borne, Beckers, Misset-Groenveld, and van Loghem (1970) showed that in cases of cold acquired haemolytic anaemia $\alpha 2 \mathrm{D}$ component only was present on the red cells. Cells from such cases, therefore, are used as test cells and are suitable provided they are correctly collected. Table IX shows the different reactions of the cells according to the method by which they are collected. To obtain the desired result it is necessary to collect the cells in warm $\mathrm{Na}$ EDTA solution (final concentration of Na EDTA: 0.01M) preferably in the syringe, otherwise the antigen antibody reaction proceeds in vitro even at room temperature, and other components of complement, $\beta_{1 \mathrm{e}}$ and $\beta_{1 \mathrm{a}}$, become absorbed onto the patient's own red cells, eg, if blood is allowed to remain in the syringe for some minutes before it is ejected into a cold ACD solution (ACD, cold, table IX), the results are quite different and other components of complement, $\beta_{1 \mathrm{e}}$ and $\beta_{1 \mathrm{a}}$, become absorbed onto the patient's own red cells; similarly in clotted samples. These may be eluted after a period of storage (table IX). Such cells can be preserved frozen until required; they may or may not be positive with anti-C5.

Because cells from cases of CAHA may not be readily available, it is useful to be able to prepare $\alpha 2 \mathrm{D}$ coated cells in the laboratory. EC are made as described above and then $0.2 \mathrm{ml} \mathrm{EC}$ packed cells are treated three or four times consecutively at $37^{\circ} \mathrm{C}$ for 45 minutes with $10 \mathrm{ml}$ fresh serum plus EDTA (final concentration of $\mathrm{Na}$ EDTA: 0.01M). The red cells so prepared are no longer agglutinated by anti$\beta_{1 \mathrm{e}}$ or anti- $\beta_{1 \mathrm{a}}$ and the positive result with anti- $\alpha 2 \mathrm{D}$ is stronger than that originally given by the EC (table X). For maximum agglutination by anti- $\alpha 2 \mathrm{D}$,

\begin{tabular}{|c|c|c|c|c|}
\hline \multirow{2}{*}{$\begin{array}{l}\text { Test } \\
\text { Cells }\end{array}$} & \multirow{2}{*}{$\begin{array}{l}\text { Treatment of } \\
\text { Test Cells at } 37^{\circ} \mathrm{C}\end{array}$} & \multicolumn{3}{|c|}{ Antiglobulin Test } \\
\hline & & $\overline{A n t i-\beta_{1 e}}$ & $A n t i-\beta_{1 a}$ & $A n t i-\alpha 2 D$ \\
\hline $\begin{array}{l}E C \\
E C\end{array}$ & $\begin{array}{l}10 \text { vol fresh serum }+ \\
\text { EDTA, repeated }\end{array}$ & ++++ & $+\div++1$ & $\begin{array}{l}+t+ \\
+t+t+\end{array}$ \\
\hline
\end{tabular}

Table X Cells coated with $\alpha 2 D$ alone prepared from $E C$

the starting EC may be made using fresh serum diluted less than 1 in 40 in the SVB (see table VI). In this case, the final red cell preparation will also be agglutinated by anti-C5.

An alternative method of preparing such cells is to react EC3 with a source of $\mathrm{KAF}$ (C3b inactivator), as shown in table VIII, although such cells are usually less active than cells from a case of cold 
acquired haemolytic anaemia. Note that the cells illustrated in table VIII are negative with anti-C5.

\section{Discussion}

In this paper the preparation of different kinds of sensitized cells has been described. They have been sensitized with an antibody of known immunoglobulin character which may, or may not fix complement; we used to judge the anticomplement activity of antiglobulin sera by the difference in reaction using these two kinds of cells. More recently, we have prepared cells coated with individual complement components in the absence of detectable antibody, which has added to the value of the test cell series. If a particular kind of sensitized cell could not be prepared in the laboratory we have used cells obtained from clinical cases where it was thought that the nature of the proteins on the cell surface was known, eg, cells from acquired haemolytic anaemia coated with $\gamma \mathrm{A}$ globulin. These cells can be preserved in the frozen state.

The notation for complement-coated cells, particularly in this paper, eg, EC, EC4, EC3, is for convenience only, and, as the cells have not been tested with a full range of anticomplement antisera, it is always possible that on the cell surface of any cell described there is some minor component which has not been detected. Nevertheless, we feel that these cells do comprise a useful series of test cells if they are considered in relation to the antisera with which they have been tested, and that useful distinctions can be made using them; for example, they can be used with multipurpose antiglobulin sera to gain a knowledge of the individual component antibodies and their respective strengths. They can also be used for comparative purposes in the antiglobulin test when the nature of the immunoglobulin or complement component on a cell sample is being considered.

An alternative way of preparing a test cell series is by coupling proteins to the red cell surface and this has been used by other workers. We have employed this technique and it is a very useful method but the proteins have to be very pure and this is not always easy to achieve. We have rather concentrated on methods of preparation of sensitized cells which are relatively easy to prepare.

With regard to the particular kinds of test cells employed, those coated with $\gamma \mathrm{M}$ globulin have always presented a problem because many antibodies of this immunoglobulin type are well known to be strong saline agglutinins. Anti-Lewis antibodies have been chosen because certain examples of them appear to be able to coat the cells at $37^{\circ} \mathrm{C}$ to such an extent that they will support agglutination by anti- $\gamma \mathrm{M}$ antisera, but at the same time give either none, or very little, agglutination in saline. A considerable amount of $\gamma \mathrm{M}$ antibody on the cell surface seems to be necessary to enable a positive antiglobulin test with anti- $\gamma \mathrm{M}$ to be detected. Thus, a potent anti-Le antibody is necessary to make these sensitized cells. It must be remembered that the more sensitive the antiglobulin technique that it used, and particularly if spinning techniques are employed, the more difficult it becomes to prepare cells coated with Lewis antibody which are negative in the control, and careful adjustment of the dose is required.

We have always been aware of the fact that there may be on sensitized cell proteins other than those revealed by the present test, and in the case of $\gamma \mathrm{M}$-coated cells we have often considered this, eg, whether additional components may be partially responsible for the positive antiglobulin test. However, we have been unable to show that this is so; for example, ELe ${ }^{a}$ cells are negative with anti-Clq and when such cells are treated with mercaptoethanol or Lewis substance the ability of anti- $\gamma \mathrm{M}$ to agglutinate them is abolished (table III).

$\gamma \mathrm{A}$-coated cells present a considerable difficulty because $\gamma \mathrm{A}$ blood group antibodies occur infrequently. We have used cells from cases of acquired haemolytic anaemia where the direct Coombs test was positive with anti- $\gamma \mathrm{A}$ and negative with all other antisera (table I). Such cells when found may be preserved frozen solid.

Anti- $\gamma \mathrm{M}$ and anti- $\gamma \mathrm{A}$ often vary in their ability to agglutinate $\gamma \mathrm{M}$-or $\gamma \mathrm{A}$-coated red cells, and anti- $\gamma \mathbf{M}$ is probably the least useful constituent of antiglobulin sera because most of the antibodies which can be detected by the use of anti- $\gamma \mathrm{M}$ are also complement fixing.

The work of Dacie, Crookston, and Christenson, as long ago as 1957, showed that in the presence of potentially haemolytic cold auto- and isoantibodies complement was bound to red cells and detectable by the antiglobulin test. They further suggested that cold antibodies probably did not exist in a demonstrably incomplete form, and that the agglutination by antiglobulin serum of erythrocytes exposed to these antibodies was due to interaction between antiglobulin serum and absorbed complement.

Thus, cells treated with highly purified anti-I antibody at low temperature in the presence of fresh serum will result in the fixation of complement and the coating of the cells with complement components. When such cells are warmed to $37^{\circ} \mathrm{C}$ Harboe (1964) showed that anti-I leaves the cells completely, and we have demonstrated also that when this occurs $\mathrm{Cl}$ also leaves the cells leaving $\mathrm{C} 4$ and later components on the cell surface. It seems 
likely that a similar process occurs when cells are treated with fresh serum at low ionic strength. Immunoglobulin material becomes coated on the cell surface and fixes complement at low ionic strength but this and $\mathrm{Cl}$ elute at normal ionic strength leaving certain $\mathrm{C}$ components on the cell surface. If, during the preparation of these cells, the incubation times are too long, all the immunoglobulin material may not be eluted from the cells at normal ionic strength.

To prepare cells coated with $\mathrm{C} 4$, cold incomplete anti-H has often been used as a source of antibody if it can be referred to as such. However, this is not entirely satisfactory and these cells, even when most carefully prepared, may be agglutinated by other antisera. We prefer, therefore, the low ionic strength method of preparing EC4 although it does require an intermediate step involving the use of a crude $\mathrm{Cl}$ preparation.

More difficult to prepare are cells coated with C3. Engelfreit et al (1970), however, in their observations showed that cells from cold acquired haemolytic anaemia agglutinated by anti- $\alpha 2 \mathrm{D}$ alone and provided such cells are carefully collected (table VIII) they form good test cells; or they might be prepared in the laboratory (table X). Some cell samples may be positive with anti-C5(Kerr, Dalmasso, and Kaplan, 1971) and our observations confirm this, also with antibodies against later $\mathrm{C}$ components. Since anti- $\alpha 2 D$ is an important component of anticomplement antisera and must be present in order to detect such cells, these are obviously very useful test cells. On the other hand, our work does lead us to believe that excessive concentration of anti- $\alpha 2 D$ may result in false positive results (Stratton and Rawlinson, to be published). Whether it is that cell samples from a proportion of individuals may, under certain circumstances, have minimal amounts of $\alpha 2 \mathrm{D}$ on their surface after collection remains to be established with certainty but it is interesting to observe in this connexion that cells from patients with familial angioneurotic oedema are agglutinated by anti $2 \mathrm{D}$ antisera and not by others in the direct antiglobulin test, so it does seem that spontaneous activation of complement could lead to these results. The fact that only $\alpha 2 \mathrm{D}$ is present in these cases is not surprising now that it is known that there are C3b inactivators in serum (Tamura and Nelson, 1967; Ruddy and Austen, 1965; Lachmann and Müller-Eberhard, 1968).

The disappearance of $\mathrm{C} 4$ from cells has been referred to by Engelfriet, von dem Borne, Beckers, Reynierse, and van Loghem (1972) and we have studied the phenomenon in vitro and illustrated it in this paper, but it seems to us that an inactivator may be present in serum which inactivates $\mathrm{C} 4$ and is different from the $\mathrm{C} 3 \mathrm{~b}$ inactivator (Stratton and $\stackrel{\mathrm{O}}{-}$ Rawlinson, to be published), although in this case $\overrightarrow{\vec{F}}$ we have not been able to detect to date any remnantsof $\mathrm{C} 4$ on the cells.

We have described cells apparently coated with $\frac{\bar{\sigma}}{\overline{0}}$ $\mathrm{C} 3 \mathrm{~b}$ alone. The critical factors in producing such $\widetilde{\widetilde{\Phi}}$ cells appear to be having a large volume of serum $\varrho$ to cells, and leaving this mixture, together with inulin, for only a very short time at $37^{\circ} \mathrm{C}$. We found, too, $\vec{O}$ that some sera appeared to be more effective than $\overrightarrow{-}$ others in producing suitably coated cells and, $\bar{\omega}$ therefore, a fairly large serum pool probably gives the best chance of success.

In all antiglobulin tests, care must be taken to. make sure that all variables are carefully controlled; in for example, the manner in which the cells are collected, the length of time they are stored after 0 collection in a particular medium, or as clotted cells, the technique of the antiglobulin test that is $\bar{z}$ employed, and the method of preparation of the sensitized cells before the indirect test. All these $\vec{\varphi}$ can have an effect on the final outcome. Particularly troublesome are false positive results occurring with anticomplement antiglobulin sera and there are many reasons for these, some not yet fully understood; all these problems will be discussed in subsequent publications.

\section{References}

Abramson, N., Alper, C. A., Lachmann, P. J., Rosen, F. S., and Jandle, J. H. (1971). Deficiency of C3 inactivator in Man. J. Immunol., 107, 19-27.

Bokisch, V. A., Müller-Eberhard, H. J., and Cochrane, C. G. (1969). Isolation of a fragment (C3a) of the third component of $\bar{\Omega}$ human complement containing an anaphylatoxin and chemotactic activity and description of an anaphylatoxin inactivator $\overline{0}$ of human serum. J. exp. Med., 129, 1109-1130.

Crawford, H., Cutbush, M., and Mollison, P. L. (1953). Specificity of incomplete 'cold' antibody in human serum. Lancet, 1, 566-567. O

Dacie, J. V. (1950). Occurrences in normal human sera of 'incomplete' forms of 'cold' auto-antibodies. Nature (Lond.), 166, 36.

Dacie, J. V., Crookston, J. H., and Christenson, W. N. (1957). 윽 'Incomplete' cold antibodies: role of complement in sensi- $D$ tization to antiglobulin serum by potentially haemolytic antibodies. Brit. J. Haemat., 3, 77-87.

Engelfriet, C. P., von dem Borne, A. E. G., Jr., Beckers, D., Reynierse, $\mathbb{N}$ E., van Loghem, J. J. (1972). Autoimmune haemolytic anaemias. V. Studies on the resistance against complement haemo- $N$ lysis of the red cells of patients with chronic cold agglutinin disease. Clin. exp. Immunol., 11, 255-264.

Engelfriet, C. P., von dem Borne, A. E. C., von dem Giessen, M., $\omega$ Beckers, D., and van Loghem, J. J. (1968). Autoimmune haemolytic anaemias. I. Serological studies with pure antiimmuno globulin reagents. Clin. exp. Immunol., 3, 605-614.

Engelfriet, C. P., Pondman, K. W., Wolters, G., von dem Borne, $\mathbb{D}$ A. E. C., Beckers, D., Misset-Groenveld, G., and van Loghem, ? J. J. (1970). Autoimmune haemolytic anaemias. III. Prepara- $\square$ tion and examination of specific antisera against complement components and products, and their use in serological studies. Clin. exp. Immunol., 6, 721-732.

Götze, O., and Müller-Eberhard, H. J. (1971). The C3-activator $\frac{\overbrace{1}}{(\mathbb{P}}$ system: an alternate pathway of complement activation. ¿ J. exp. Med., 134, 90s-108s.

Harboe, M. (1964). Interactions between ${ }^{131}$ I-trace labelled cold $\widetilde{<}$ agglutinin, complement and red cells. Brit. J. Haemat., 10, 339-346.

Jenkins, D. E., Jr., Christenson, W. N., and Engle, R. L., Jr. (1966). 
Detection of complement components on unlysed erythrocytes from acid hemolysis and thrombin test reactions in paroxysmal nocturnal hemoglobinuria. J. clin. Invest., 45, 796-802.

Kerr, R. O., Dalmasso, A. P., and Kaplan, M. E. (1971). Erythrocyte-bound $\mathrm{C5}$ and $\mathrm{C6}$ in autoimmune hemolytic anemia. J. Immunol., 107, 1209-1210.

Lachmann, P. J., and Müller-Eberhard, H. J. (1968). The demonstration in human serum of 'conglutinogen-activating factor' and its effect on the third component of complement. $J$. Immunol., 100, 691-698.

Mollison, P. L., and Polley, M. J. (1964). Uptake of $\gamma$-globulin and complement by red cells exposed to serum at low ionic strength. Nature (Lond.), 203, 535-536.

Müller-Eberhard, H. J., Dalmasso, A. P., and Calcott, M. A. (1966). The reaction mechanism of $\beta_{10}$ globulin $\left(C^{\prime} 3\right)$ in immune hemolysis. J. exp. Med., 123, 33-54.

Nicol, P. A. E., and Lachmann, P. J. (1973). The alternate pathway of complement activation. The role of $\mathrm{C3}$ and its inactivator (KAF). Immunol., 24, 259-275.

Rapp, H. J., and Borsos, T. (1963). Effects of low ionic strength on immune haemolysis. J. Immunol., 91, 826-832.

Rockey, J. H., and Kunkel, H. G. (1962). Unusual sedimentation and sulfhydryl sensitivity of certain isohemagglutinins and skin-sensitizing antibody. Proc. Soc. exp. Biol. (N.Y.), 110, 101-105.

Ruddy, S., and Austen, K. F. (1969). C3 inactivator of man. I. Hemolytic measurement by the inactivation of cell-bound C3. J. Immunol., 102, 533-543.

Stratton, F. (1961). Complement-fixing blood group antibodies with special reference to the nature of anti-Les. Nature (Lond.), $190,240-241$.

Stratton, F. (1966). Zymosan coated particles used to prepare anti- $\beta_{1}$. Vox Sang (Basel). 11, 232-237.

Stratton, F., Gunson, H. H., and Rawlinson, V. I. (1962). The preparation and uses of antiglobulin reagents with special reference to complement-fixing blood group antibodies. Transfusion (Philad.), 2, 135-149.

Stratton, F., and Rawlinson, V. I. (1965a). The action of the first component of complement on cells sensitized with blood group antibody. Brit. J. Haemat., 11, 592-599.

Stratton, F., and Rawlinson, V. I. (1965b). Interaction between human serum complement and normal human red cells at low ionic strength. Nature (Lond.), 207, 305-306.

Stratton, F., Rawlinson, V. I., Chapman, S. A., Pengelly, C. D. R., and Jennings, R. C. (1972). Acquired hemolytic anemia associated with IgA anti-e. Transfusion (Philad.), 12, 157-161.

Stratton, F., and Renton, P. H. (1958). Practical Blood Grouping. Blackwell, Oxford.

Stratton, F., Smith, D. S., and Rawlinson, V. I. (1968). 19S $\gamma \mathrm{M}$, followed by $7 \mathrm{~S} \gamma \mathrm{G}$ anti-Jk antibodies associated with pregnancy. Clin. and exp. Immunol., 3, 81-90.

Tamura, N., and Nelson, R. A., Jr. (1967). Three naturally-occurring inhibitors of components of complement in guinea-pig and rabbit serum. J. Immunol., 9, 582-589.

West, C. D., Davis, N. C., Forristal, J., Herbst, J., Spitzer, R. (1966). Antigenic determinants of human $\beta_{1 c}$ and $\beta_{18}$ globulins. J. Immunol., 96, 650-658.

Worlledge, S. M., and Blajchman, M. A. (1972). The autoimmune haemolytic anaemias. Brit. J. Haemat., 23, Suppl., 61-69. 